\title{
AZ INDIVIDUUM BIZTONSÁGA VIDÉKI TÉRBEN ${ }^{1}$ SECURITY OF THE INDIVIDUAL IN COUNTRYSIDE SPACE
}

\section{Jankovics Kornélia}

\author{
mestertanár \\ Szent István Egyetem, Gazdaság és Társadalomtudományi Kar \\ E-mail: iroda.jankovics@t-email.hu
}

\section{Összefoglalás}

Jelen tanulmányt az individuum szemszögéből tekintett vidéki biztonság egyes, főbb dimenzióinak elemzésére szántam. A "kitekintés" közel sem terjedhet ki a biztonságnak a vidéki térben létező valamennyi aspektusára, hiszen a vidék biztonsága kérdéskörében felmerülő, számba vehető valamennyi szegmens a tanulmány kereteit sokszorosan túlhaladják, az minimálisan egy doktori értekezésben kitüzött cél lehet. A biztonság főbb dimenzióinak bemutatása csupán egy általános - és nem minden dimenziót érintő - kép felfestésére vállalkozhat, de mindenképpen alkalmas lehet arra, hogy a téma kibontására kedvet érzőket tovább gondolkodásra sarkallja.

\begin{abstract}
My intention with the present study was to analyse some of the major dimensions of the security in the countryside considered from the individual's point of view. The "outlook" is very far from addressing all the aspects of security existing in the countryside space, as all the segments that arise and that can be taken into account in the scope of the security of the countryside multiply exceed the framework of the study and can minimally be the goal of a $\mathrm{PhD}$ thesis. The goal of the presentation of the major dimensions of security may only be the depiction of a general picture that does not touch upon every dimension, but it can, by all means, be suitable for encouraging those feeling like analysing the topic more deeply to think further on.
\end{abstract}

Kulcsszavak: biztonság, individuum, vidékbiztonság, vidékfejlesztés, vidéki térség

JEL besorolás: Z10

LCC: S544-545.53

\section{Bevezetés}

Az individuum biztonsága csak az élet különböző területein létező jelenségek bonyolult szempontrendszerében vizsgálható. Egyfajta sorvezetőként talán az ún. komplex biztonság körülírása funkcionálhat, miszerint az nem elsősorban a "köz" biztonsága, hanem a személy biztonsága, perszonális jog, amely a társadalmi létből fakadó általános elvárásoknak felel meg. Ilyenek például a megélhetés biztonsága, a társadalom szociálpolitikai támogató rendszeréhez való hozzáférés, a közegészségügyi ellátás különböző szintjeinek igénybevétele, mindezeken keresztül a pszichológiai jellegü nyugalom, a lelki béke állapota. Természetesen ide csatlakozik a köz- és magánterületeink rendjének, és a hon megnyugtató védelmének általános igénye is, és természetesen e tartalmi kört még lehetne folytatni. (Szilágyi-Boldizsár, 2016)

\footnotetext{
1 A tanulmány a KÖFOP-2.1.2-VEKOP-15-2016-00001 azonosítószámú, „A jó kormányzást megalapozó közszolgálat-fejlesztés” elnevezésű kiemelt projekt keretében, a Nemzeti Közszolgálati Egyetem felkérésére készült.
} 
A tanulmány szempontjából a vidék adta biztonság kérdéskörét járjuk körbe, mindazonáltal már itt megjegyezve, hogy jelen írás - a terjedelmi korlátok miatt - csupán vázlatos elemzést tükrözhet a téma igazi kibontása nélkül.

A biztonság kapcsán egyik fö kérdés, hogy mit is értünk ez alatt. A fogalom igen sokrétü, összetett, és számtalan aspektusból vizsgálható.

Kérdés: Az-e a biztonság, hogy nem kell félnem, hogy mások jogtalanul megtámadnak és testi integritásomat elveszítem ?

Válasz: Igen, az is az, de ennél jóval több.

Kérdés: Az-e a biztonság, hogy a megélhetésemet folyamatosan biztosító munkalehetőség révén megkeresett - vagy egyéb, más módon kapott - jövedelemmel rendelkezem?

Válasz: Igen, az is az, de ennél jóval több.

Kérdés: Annak tudata-e a biztonság, hogy balesetem vagy megbetegedésem esetén időben jutok adekvát segítséghez?

Válasz: Igen, az is az, de ennél jóval több.

Kérdés: Olyan állapot-e a biztonság, amelyben egy katasztrófahelyzet esetén életem, testi épségem, vagyontárgyaim épsége szavatolt?

Válasz: Igen, az is az, de ennél jóval több.

Kérdés: Az a helyzet-e a biztonság, melyben önmagam - vagy éppen gyermekem - olyan ismeretgazdagító metódusokhoz juttatható, mely révén elérhető - a saját lábon álló - testi-lelki jólét?

Válasz: Igen, az is az, de ennél jóval több.

Kérdés: Az-e a biztonság, hogy ún. stresszorok nélkül élhetem mindennapjaim?

Válasz: Igen, az is az, de ennél jóval több.

\section{Individuum és individuum elméletek}

Az idegen szavak és kifejezések kéziszótára szerint az individuum egyrészt „Egyed, önállóan létező élő szervezet”, másrészt fogalmazva „Egyén, egyéniség.” (Bakos, 1994)

A Magyar Értelmező kéziszótár úgy fogalmaz, hogy az individuum önmagában tekintett lény vagy dolog; egyén, egyed. (Juhász-Szője-O.Nagy-Kovalszky, 1982)

Ajtony Árpád megfogalmazásában az individuumok olyan egyének, akik elég felnőttek ahhoz, hogy vállaljak szavaik következményeit, illetőleg akik az ún. fejlett országokban a csoportoktól már függetlenek, olyanok, akik a saját életüket egyre önállóban szervezik.(Ajtony, 2013)

Norbert Elias szerint az individuum azt jelenti, hogy minden ember autonóm vagy autonómmá lesz, vagyis maga irányítja életet, ugyanakkor azt is, hogy az egyes emberi lény némiképp különbözik is az összes többitől vagy talán különböznie kellene. (Elias, 1991)

Tallér Ferenc úgy véli, hogy az individuum fogalma elválaszthatatlanul összekapcsolódik a méltóság, a szabadság (a szabad akarat) és az autonómia (mint önmagunk megalkotása) gondolatával. (Tallár, 2004)

A wikipédia szerint: Az individuumokon, más szóval egyéneken, térben és időben behatárolható, egy biológiai vagy társadalmi csoporttól jól elkülöníthető személyeket értünk. 
Általában - annak ellenére, hogy minden ember körülbelül azonos fizikai felépítéssel rendelkezik (általában mindenkinek ugyanott van a lába, keze, feje, a fején a szemek, az orr, a fülek és a szája) - az emberek számára mégsem okoz gondot a körülöttük levő többi ember felismerése és egymástól való elkülönítése. Ez a valami, ez a megkülönböztető jel vagy tulajdonság, ami alapján egyik embert megkülönböztetjük a többi embertől, teszi individuummá az embert.

Arisztotelész az individuális dolgokat specieseknek (fajoknak), a specieseket pedig genusoknak (nemeknek) rendelte alá. Az individuális dolog a felosztások legutolsó tagjai: például Odüsszeusz kutyája, Argosz mint individuum a kutya speciesébe tartozik, a kutya pedig a „,négylábú bundások” osztályába. A bundás négylábúak a cetfélékkel együtt az elevenszülők osztályába tartoznak, az elevenszülők pedig a tojásrakó állatokkal együtt a melegvérüek osztályába, a meleg vérü állatok meg a „,vértelenekkel” együtt alkotják az élőlények osztályát. Minden osztály a fölötte álló, őt magában foglaló osztályhoz való viszonyában speciesnek, az alatta levő osztályhoz való viszonyában pedig genusnak minősül. A felosztás legalsó tagja (lat. infima species), jelen esetben ,a kutya” után következők, nem sorolhatóak már semmilyen osztályba, mivel ezek egyedi tulajdonsággal rendelkeznek, csak egy létezik belölük a világon (jelen esetben Argosz). Az individuumot, a specieshez hasonlóan Arisztotelész szubsztanciának tekintette. Az individuumot pedig abban különböztette meg a speciestől (például ember), hogy az individuumnak (például Szókratész) vannak olyan tulajdonságai is, melyek nem sorolhatók be a species (ember) szubsztanciájához. Az individuális szubsztanciák pedig abban különböznek egymástól, hogy térben jól elkülöníthetők egymástól. Két emberi egyednek a szubsztanciális formája és lényege ugyanaz, de az egyiknek itt van a teste a másiknak meg ott.

Descartes az öntudat evidenciájának bizonyításával határolja el az individuumot a külvilágtól. „Gondolkodom tehát vagyok” tétele úgy értelmezhető „Gondolkodom, tehát gondolkodó lényként létezem", ebböl pedig azt a következtetést vonhatjuk le, hogy rendelkezünk egy olyan tulajdonsággal amely segítségével behatárolhatjuk magunkat: ez az öntudat. Öntudatom meglétét világosan és elkülönítetten (clare et distincte) élem meg.

Hegel Kant transzcendentális filozófiáját fejlesztette tovább. Nála lezárult az énnek mint alapnak a problematikája, és az én az észben, a legteljesebb valóságú abszolút szellemben megszüntetve-megőrizve és felemelkedve van jelen.

Hegel szerint az egyéni, individuális tudat az abszolút szellem (Isten) öntudatra jutási folyamatának a szerves része. Az abszolút eszme (a fejlődés kiindulópontját jelentő, öntudatára még nem jutott Isten) kibocsátja magából a természetet, majd ebből a természetből kiemelkedik a szellem (az egyéni és a társadalmi tudat), melynek fejlődése során az abszolút eszme felismeri önmagát a világban, teljesen önmagára reflektálódik, teljes öntudatra jut.

Schopenhauer szerint csak a megismerő individuum létezik, az őt körülvevő világ csak mint képzet adott. Az objektumok csak olyan módon adottak, ahogyan a szubjektum által feltételezettek: „A világ az én képzetem”.

Soren Aabye Kierkegaard arra keresve választ, hogy egy létező szubjektum, hogyan kerülhet kapcsolatba Istennel, tesz kísérletet az egyes egyén az individuum meghatározására. Ezen a ponton Kierkegaard szembehelyezkedik a német idealizmussal, különösen Hegellel, aki szerint az individuum alá van rendelve a történelemnek, és azt hangoztatta, hogy mindenekelött az egyes egyén konkrét létfeltételeit kell felfogni, azaz „magamat a létezésben megérteni”. 
Nietzschenél az individuum az ember fölötti ember, vele szemben állnak a csordaemberek, melyet homogén masszaként képzelhetünk el. Az ember fölötti ember, az Übermensch a hagyományos értékekkel szembeni tökéletes szabadságával tűnik ki. Cselekvése földi mértékhez igazodik: eröre, vitalitásra, hatalomra törekszik. Vele szemben állnak a csordaemberek, akik egy elgondolt istendiktátum előtt hajlonganak és a részvét és gyengeség erkölcse előtt hódolnak.

A tanulmány során nem merülök bele az individuumnak a fenti - esetenként a filozófia nehezen értelmezhető bugyrából fakadó - értelmezésébe, hanem az annak legáltalánosabban elfogadott fogalmát, azaz, mint egyént veszem alapul az alábbiakban jelölt - önkényesen és nem teljes körúen kiválasztott - dimenziók vizsgálatán keresztül.

\section{Rendészeti dimenzió}

Az egyén biztonságát sokan azonosítják azzal a helyzettel, amelyben egy állampolgárnak nem kell attól tartania, hogy életét, testi épségét vagy vagyontárgyait támadás éri, azonban ez figyelemmel a biztonság fentebb kifejtett fogalmára - közel sincs így. Mindazonáltal a biztonság egyes dimenziói közül kétségtelenül kitüntetet figyelmet kell, hogy kapjon a rendészeti területhez tartozó azon deliktumok megvalósulási esélyének számbavétele, melyek középpontjában a testi-lelki integritás sérthetetlensége és a vagyonbiztonsághoz füződő érdek elleni jogtalan támadása áll.

Objektív - szubjektív biztonság (biztonságérzet)

Az individuum rendészeti aspektusú biztonság értelmezése során legalább két fogalmat tisztázni célszerü. Ezek az objektív és szubjektív biztonság, melyek közül ez utóbbit szokás szubjektív biztonságérzetnek is nevezni.

Objektív biztonság: A biztonságnak életminőség oldaláról való megközelítése, amely az egyéni és közösségi érdekek formális megjelenítése mellett, az erőforrások, a képességek, a mérhető hatások, statisztikailag megjeleníthető mértékek alapján vizsgálja az összefüggéseket.

Szubjektív biztonság (biztonságérzet): A biztonságnak az egyéni tapasztalatok, az érintettség mértéke és minősége oldaláról való megközelítése, elsősorban a szubjektív érzékelés és értékelés folyamatainak jelentőségét hangsúlyozza, s így az emberek szubjektív közérzete alapján méri a társadalom fejlödését és az életminőség mértékét, abból kiindulva, hogy az átlagember tudja leginkább megítélni saját életminőségét. (Beregnyei, 2008)

A két fogalom elhatárolása, egyben lényege talán úgy foglalható össze, hogy az objektív biztonság a valós biztonsági helyzetet jelenti, a szubjektív biztonság pedig ennek tükröződése az emberek tudatában. (Csordás, 2008)

Kutatásokból megállapítható, hogy az áldozattá válás lehetősége - azaz az objektív biztonság - és a szubjektív biztonságérzet között nemhogy összefüggés nincs, hanem éppen fordítottja igaz, tehát pont azokon a területeken, régiókban vagy országokban a legmagasabb, amelyekben a legkisebb az áldozattá válás esélye. Ezt támasztja alá egy 2005-ös, Európa 17 országában végzett felmérés a szubjektív biztonságérzetről. Ez jelentős eltérést mutathat az objektív biztonsági mutatóktól, mert a felmérés szerint a „bünözéstől való legerősebb félelem éppen a legalacsonyabb áldozattá válási arányokat felmutató országokban mutatkozik". A félelemérzet kollektív felfokozódása tömeges, teljesen irracionális és indokolatlan következményeket vonz be, így történhetett, hogy a 9/11-i World Trade Center elleni merénylet után a polgárok 
tömegesen tértek át közúti közlekedésre a légi közlekedésröl, ami csaknem 1600-al növelte meg a közúti balesetben elhalálozottak számát. További probléma, hogy a statisztika mint „objektív” biztonságot mutató eszköz nem koherens a lakosság szubjektív biztonságérzetével. (Vári, 2015)

A Vidékfejlesztési Programban az állam önönmaga deklarálja, hogy a vállalkozói kedvet, aktivitást jelentősen visszafogja, valamint a vidéki lakosság biztonságérzetét, és ezen keresztül az életminőségét is rontja a sok esetben nem megfelelő vagyonbiztonság, különösen a lakott területeken kívül eső mezei és erdei javak sérelmére elkövetett büncselekmények nagy száma.

Ugyanígy említeném a Nemzeti Vidékstratégia 2012-2020 deklarációját. Eszerint jelentős problémát okoz a gazdálkodást veszélyeztető rossz vagyonbiztonság. A föleg falvakat, külterületeket, tanyákat érintő betörések, termény- és állatlopások egyre gyakoribbak. A gazdák egyes térségekben teljesen kiszolgáltatottá váltak a bünelkövetőknek.

Éjjelente gazdaságaikat őrizniük kell. 2009-ben kistérségeink 10\%-ában mind a vagyon, mind pedig a személy elleni büncselekmények százezer lakosra jutó száma meghaladta az országos átlagot. A csak vagyon elleni büncselekményeket vizsgálva ez már minden negyedik vidéki kistérségünkre igaz.

A büncselekmény kategóriában a legkedvezöbb helyzetü települések között egyetlen város sem található. (1. ábra) A jellemzően kis lélekszámú települések között legnépesebb a 6 ezer lakost el nem érő Kartal. A térképen megfigyelhető, hogy ezeknek a biztonságos kistelepüléseknek legjelentősebb halmaza Győr-Moson-Sopron, Vas és Veszprém megyékben található.

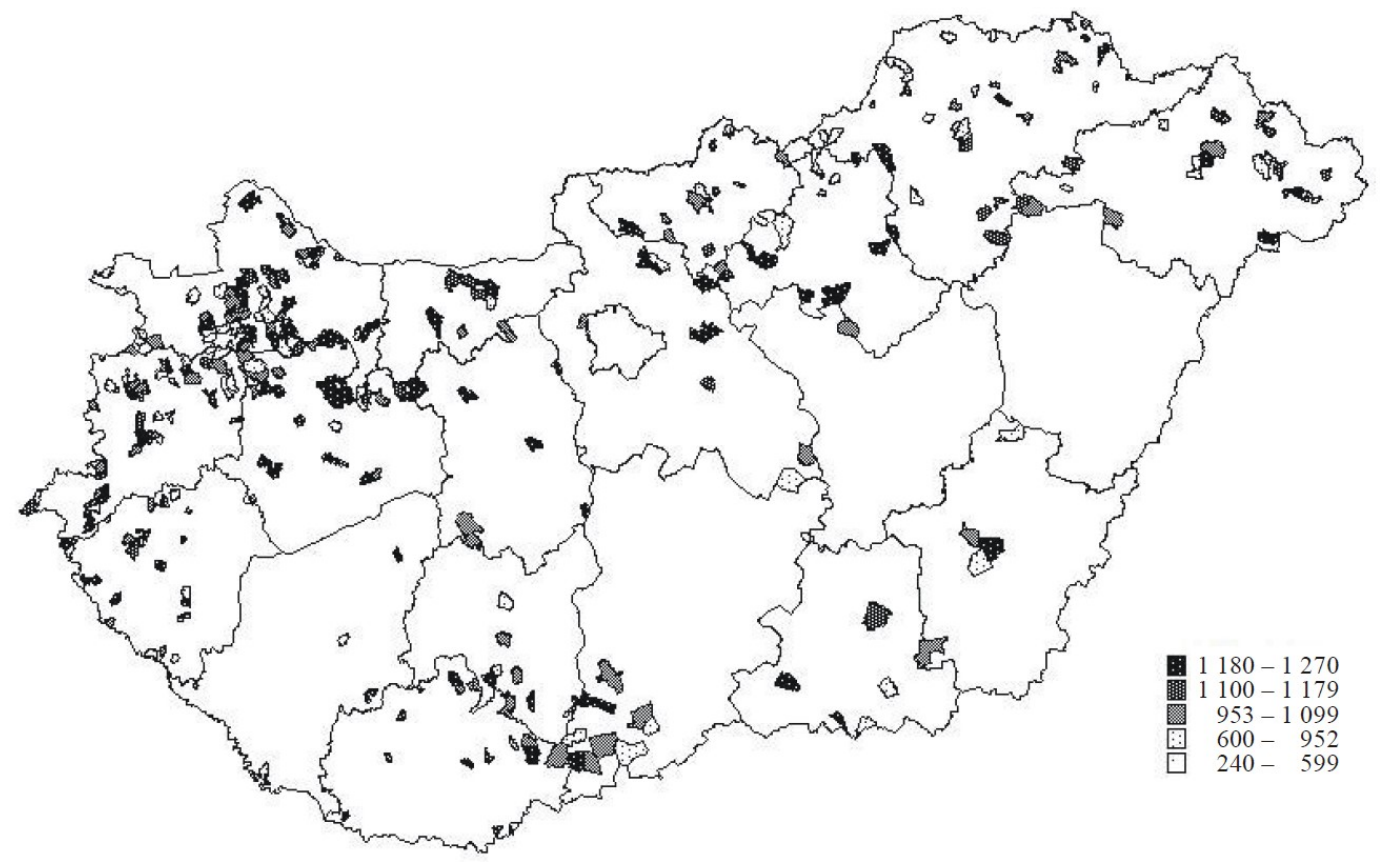

\section{1. ábra: A 300 legkedvezőbb helyzetü település az ismertté vált/regisztrált}

bűncselekmények 100000 lakosra jutó számának számtani átlaga alapján (2001-2011) Forrás: Patkós-Tóth, 2012

A 300 legkedvezőbb helyzetű település jelentős része a Nyugat-Dunántúlon található, kisebb számban a Dél-Dunántúlon, illetve Észak-Magyarország nehezen elérhető aprófalvas térségeiben is (2. ábra). Érdekesség, hogy ebben a csoportban csupán két 3 ezer lakos feletti 
település található, Pilisszentiván és Földes; valamint nyolc olyan kistelepülés is van, ahol a mutató értéke nulla.

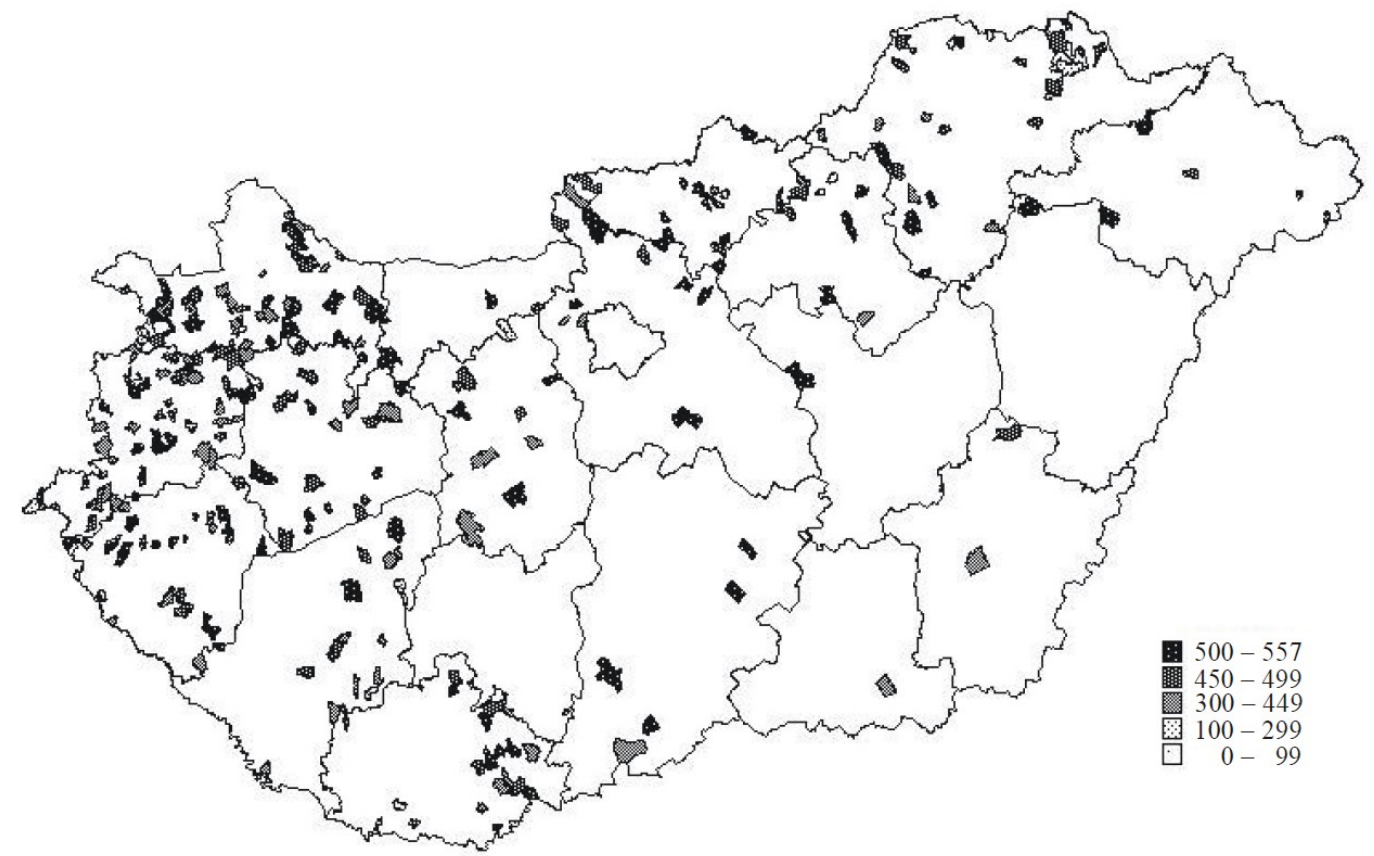

\section{2. ábra: A 300 legkedvezőbb helyzetü település az ismertté vált/regisztrált bünelkövetők} 100000 lakosra jutó számának számtani átlaga alapján (2001-2009)

\section{Forrás: Patkós-Tóth, 2012}

Mindazonáltal e kérdéses elemző tanulmány rámutat arra is, hogy egyértelmüen beazonosítható, hogy Északkelet-Magyarország számos településén magas a 100.000 lakosra jutó bünelkövetők száma (3. ábra), azaz az a megállapítás tehető, hogy leginkább az elmaradottabb térségekben magasabb a bünelkövetök gyakorisága, külön is megjegyezve, hogy ebben a kategóriában is igen magas az aprófalvak aránya, ahol alig néhány bünelkövető is a legrosszabbak közé taszíthatja a települést.

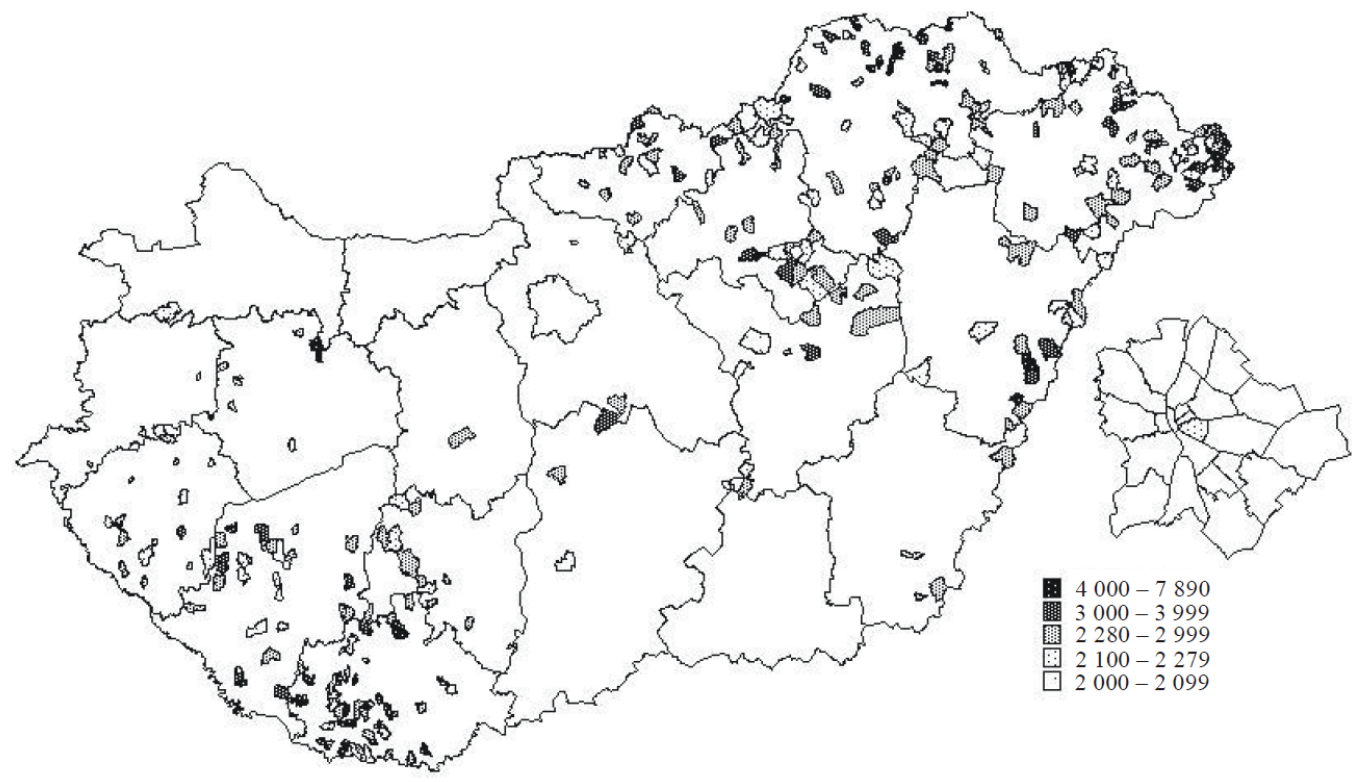




\section{3. ábra: A 300 legkedvezőtlenebb helyzetü település az ismertté vált/regisztrált bünelkövetők 100.000 lakosra jutó számának számtani átlaga alapján (2001-2011) Forrás: Patkós-Tóth, 2012}

Tanulmányunk szempontjából kiemelést érdemel az, hogy a kriminológusok már régebben megállapították, hogy a városok bünözési intenzitása magasabb, mint a községeké, és a bünözés intenzitásának növekedése egyenesen arányos a települések népességszám-növekedésével.

A nagyvárosi anonimitás, az itt élő nagyszámú potenciális bünelkövető, a sérthető értékek koncentrálódása, a legtöbb kihívás, elkövetési alkalom, az elkövetők felderítésének kisebb aránya magyarázza a nagyobb települések kimagasló számait. (Dávid, 1988)

Továbbgondolásra érdemes, hogy az állam irányítói bizonyos kriminálstatisztikai adatokat is figyelembe vehetnének az elmaradottság meghatározásakor, illetve tágabban értelmezve: a területfejlesztési programok megfogalmazásakor is nagyobb hangsúlyt lehetne fektetni ezen társadalomstatisztikai jellemzőkre.

\section{Munkahelyi-Pénzügyi dimenzió}

Az individuum biztonságának egyik kitüntetett szegmense az az anyagi bázis, amely az egyéni biztonságérzet szintjét jelentősen befolyásolja.

A Vidékfejlesztési Program 2014-2020 segítséget nyújt abban, hogy hogyan is értékelhetjük a vidék vonatkozó dimenzióját. Eszerint a vidék gazdasági fejlettsége jelentősen elmarad az uniós átlagtól, annak felét sem éri el (47\%), míg az ország egészének gazdasági fejlettsége eléri az uniós átlag kétharmadát. A vidéki térségekben az ezer före jutó regisztrált KKV-k száma megegyezik az országos átlaggal $(117 \mathrm{db})$, azonban a müködő KKV-k száma már jelentősen elmarad attól (vidéki térségek: 47,9 KKV/ezer fö, országos átlag: 70,2 KKV/ezer fö). Míg a 2 millió euró alatti éves árbevételt elérő KKV-k egyharmada müködik a vidéki térségekben, addig a nagy árbevételt (>10 millió euró) produkáló KKV-knak csak az egynegyede $(23,43 \%)$ található vidéken (forrás: KSH).

Az 1-9 föt foglalkoztató mikrovállalkozások alkotják a vidéki gazdaság meghatározó vállalkozói szegmensét. 2009-ben közel két és félszerese volt az egy lakosra jutó nettó jövedelem a fóvárosban és térségében, mint a legalacsonyabb jövedelmi kategóriába tartozó vidéki kistérségek esetében. A vidéki területek foglalkoztatási rátája 52,4\% volt, ez jóval az uniós átlag alatt marad (62,3\%).

Vidéki térségeinkben 2009-re - főleg az ország keleti, észak-keleti és dél-dunántúli térségeiben - összefüggő zónákat alkottak a kiugróan magas munkanélküliséggel rendelkező térségek. Egyes kistérségekben ez 20-25\% körül alakult, miközben pl. a fővárosban ennek nagyjából az ötöde ez az érték. Ezek a kedvezőtlen folyamatok 2010-ben megálltak, a munkanélküliség azóta csökken (2010-es 11.2\%-ról 2013-ra 10.2\%-ra), bár a vidéki területekre jellemzően továbbra is az átlagosnál alacsonyabb foglalkoztatottsággal és magasabb munkanélküliséggel rendelkeznek. A munkanélküliség a 15-24 év közöttiek esetében a legmagasabb, országos átlagban és vidéken egyaránt $28 \%, 2012$-ben az országos átlag (7,3\%) közel négyszerese. Az alacsony jövedelmüek aránya a vidéki területeken magasabb a városias településeken élőkénél. A vidéki térségek demográfiai helyzete folyamatosan romlik, a vidéki társadalmak elöregednek. Az elöregedésen túl az európai vidéki térségek döntő többségére jellemző migráció is komoly problémát jelent vidéken: a különbözet csaknem 27 ezer fő volt a vidéki térségek rovására 2002 és 2011 között. Fontos megemlíteni a vidéki népesség elöregedését, az 
50 év feletti gazdálkodói réteg megújulási és alkalmazkodási hajlandóságának csökkenő tendenciáját.

A vidék mezőgazdasági eltartóképessége súlyos mértékben megcsappant a tradicionális ipari körzetek összeomlásával együtt, ezért a vidékfejlesztés az utóbbi évtizedekben fontos válságkezelési kérdéssé lett. A rendszerváltás hozta gazdasági, társadalmi változások következtében a mezőgazdasági dominanciájú települések egyre kedvezőtlenebb helyzetbe kerültek, melynek munkahelyek elvesztése, magas munkanélküliség, elvándorlás és elöregedés lett az eredménye. (Bainé, 2003)

\section{Szociális dimenzió}

A Magyarországon kialakított szociális biztonsági rendszer azonos metodikát mutat az Európai Unióban alkalmazott meghatározások szerinti beosztás, a szociális ellátások és az azokat adminisztráló szervezetrendszer szempontjából. A szociális biztonsági rendszer a következő meghatározásokat definiálja: szociális védelem (social protection), szociális biztonság (social security), társadalombiztosítás (social insurance), szociális segélyezés (social assistance).

A szociális védelem a legnagyobb halmaz, mely valamennyi szociális támogatási formát magában foglalja, úgy mint a biztosításon alapuló ellátás, az univerzális ellátás és a segélyezési ellátás halmazt. Ide tartoznak: a betegség, az anyaság, a rokkantság, a fogyatékosság, a munkanélküliség esetén járó ellátások, az öregségi ellátások (nyugdíjak és nyugdíjszerü ellátások), a hozzátartozói ellátások, a családi ellátások, a szociális ellátások.

A szociális biztonság alatt a szakemberek a társadalombiztosítási ellátásokat, az univerzális, alanyi jogon járó ellátásokat, és a különleges, nem járulékalapú ellátások körét értik, melyek az első két csoportba tartozó ellátásokat kiegészítik vagy helyettesítik. Magyarországon kötelező társadalombiztosítás van, mely a szolidaritáson, a biztosítási elven, mint pl. az egészségbiztosítás, nyugdíjbiztosítás, és munkanélküli biztosítás alapul. A társadalombiztosítási ellátásokra jogosultsága annak van, aki biztosítottá válik vagy jogszabály alapján annak minősül. Ilyenek különösen a munkavállalók, a vállalkozók..

A szociális védelem központi, regionális és helyi irányítását a kormányzati szervek biztosítják és látják el. Jelenleg ebbe a körbe tartozik a Nemzeti Erőforrás Minisztérium, Nemzetgazdasági Minisztérium, Nemzeti Egészségbiztosítási Alapkezelő, Országos Nyugdíjbiztosítási Főigazgatóság, Nemzeti Foglalkoztatási Szolgálat, Magyar Államkincstár, a helyi önkormányzatok. A szociális ellátó rendszerek elhelyezkedése összefüggést mutat az adott régió településszerkezetével, az ott élő népesség korösszetételével, demográfiai jellemzőivel, gazdasági-foglalkoztatási lehetőségeivel. A régiók specifikus feladatokat hoznak magukkal. A városokban, nagyvárosokban, de különösen Budapesten az idősgondozás mellett nagy hangsúlyt kap a gyermekvédelem, a hajléktalanok gondozása. A kisebb településeken, tanyákon pedig elsősorban az idősek gondozása a meghatározó. Az ország nyugat-dunántúli részén 91; dél-dunántúli részén 90; észak-magyarországi részén $80 \%$ a 2000 főnél kisebb lélekszámú települések aránya. Ez az élő népesség 30-34\%-a. Ezeken az országrészeken a falugondnokként foglalkoztatottak létszáma jelentős. A tanyagondnokként foglalkoztatottak pedig a dél-alföldi régióban mutatnak kiemelkedő számot az ország átlagához képest.

A téma részletes boncolgatása jelen dolgozatnak nem feladata, az önálló tanulmányt igényelne, tekintve, hogy igen sokrétü és terjedelmes ismeretanyagra épül. A vidéki biztonság kapcsán ezen dimenzióban kiemelendő azonban az, hogy a szociális biztonság halmazát meghatározóan a társadalombiztosítási ellátások töltik ki. A Társadalombiztosítási ellátásra való jogosítottság 
feltétele a biztosítotti jogviszony, melynek alapja olyan munka, melyet az állam a biztosítás szempontjából elismer. Ezek köre tipikusan: munkaviszony, vállalkozói jogviszony, közfoglalkoztatotti jogviszony. Nem minősül biztosítotti jogviszony a bejelentés nélkül foglalkoztatottak (ún. fekete munka) és ebből jövedelmet szerzők, a munkanélküliek többségének köre. Ez a két dimenzió sajnálatos módon éppen a vidéken élők körében jelentős. A Nemzetgazdasági Minisztérium adatai szerint 2017-ben az ellenőrzéssel érintett munkavállalókhoz viszonyítva a mezőgazdaságban - mely a vidéken élők legfőbb anyagi bázisa - volt a második legnagyobb arányú a feketefoglalkoztatás.

\section{Egészségügyi dimenzió}

2013-ban egy szakcikk arról számolt be, miszerint a fővárosban más a helyzet, ott nincs akkora orvoshiány, mint vidéken, ahol állcsontsebészt nehezebb találni, mint fehér hollót (pedig az autós baleseteknél gyakran törik az arccsont). A Gyógyszerészeti és Egészségügyi Minőség- és Szervezetfejlesztési Intézet föigazgatója szerint a jövőben az egészségügy kétarcúvá válik, a következő években lesznek „uniós” és „uniótlan” kórházak és Budapest olyan szinten szakad le a vidék mögött, ami - a válságon kívül - semmilyen ésszerủ érvvel nem indokolható. 2017. nyarán az egészségügyért felelős államtitkár pedig kijelentette, hogy „Az elmúlt időszakban több mint 500 milliárd forintot költöttünk európai uniós forrásokból az egészségügy fejlesztésre. Ezekből a forrásokból a vidéki Magyarország egészségügyi ellátórendszere nagyrészt megújult".

Az egészségügyi ellátórendszerből a háziorvosi ellátás, az ügyeleti szolgálat, a járóbetegszakellátás valamint a sürgősségi mentés az, amely vonatkozásában érdemes a különbségeket megvizsgálni, ugyanis ezek a területek bírnak a vidéki térben igazán relevanciával.

\section{A KSH 2016-os „Megyék, régiók statisztikai zsebkönyve” statisztikai adatai szerint tetten érhetőek az ország egészségügyi egyenlőtlenségeit.}

Az alábbi ábrából kiolvasható, hogy főleg a háziorvosoknál a vidék leszakadása jelentős. 2015ben Budapesten 7704 beteg jutott egy háziorvosra, miközben a többi régióban - Pest megyét leszámítva - mindenhol 11 ezer feletti ez a szám. Ilyen szempontból szinte mindegy, hogy a Dunántúlon vagy az Alföldön lakik valaki. (4. ábra) A gyermekorvosok betegforgalmánál valamelyest kiegyenlítettebb a helyzet, de ott is szembetünő a különbség. (5. ábra)

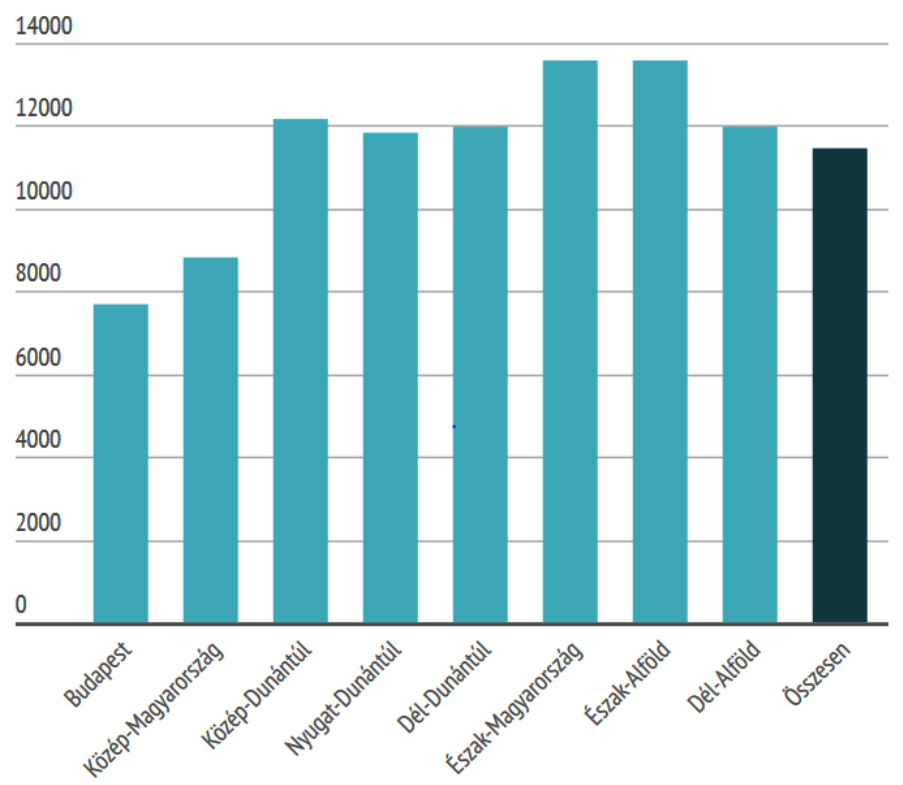


Forrás: KSH, 2016

\section{4. ábra: Egy háziorvosra jutó betegforgalom}

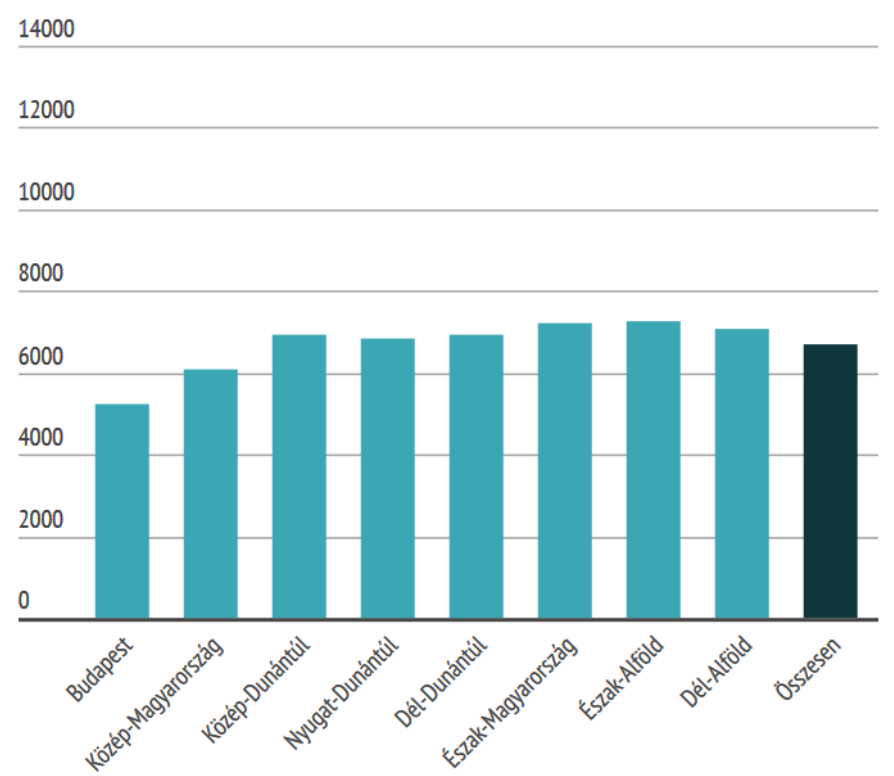

Forrás: KSH, 2016

\section{5. ábra: Egy házi gyermekorvosra jutó betegforgalom}

\section{Következtetések, javaslatok}

A tanulmányt az individuum szemszögéből tekintett vidéki biztonság egyes, főbb dimenzióinak elemzésére szántam. E kitekintés közel sem terjedhetett ki a biztonságnak a vidéki térben létező valamennyi aspektusára, hisz az e kör kontextusában felmerülö, számba vehető valamennyi szegmens a tanulmány kereteit sokszorosan túlhaladják, az minimálisan egy doktori értekezésben kitüzött cél lehet.

A biztonság főbb dimenzióinak bemutatása csupán egy általános - és nem minden dimenziót érintő - kép felfestésére vállalkozhatott, az azok mélyebb rétegeiben meghúzódó összefüggések, jelenségek cizellált elemzése még bőven ad a téma kibontására kedvet érzőknek lehetőséget. Ehelyütt talán az is várható volna, hogy valamiféle egyértelmü állásfoglalást tegyek abban a kérdésben, hogy hol van nagyobb biztonságban az állampolgár, vidéken avagy „nem vidéken”. E kérdésben történő nyilatkozattételre azonban nem vállalkoz(hat)ok, mégpedig azért, mert - határozott álláspontom szerint - a biztonság fogalmának szubjektív értelmezési lehetőségei miatt ilyen válasz felelősen senki által nem adható. Választ csupán a konkrét biztonsági dimenziók kapcsán lehet adni, de semmiképpen nem általános érvénnyel ott sem, melynek egyik fö oka az egyes individuumok bonyolult rendszerében létező értékfelfogásban érhető tetten. Lehet, hogy egy individuum a munkahelyi-anyagi dimenzióban kevésbé érzi magát a vidéki térben biztonságban, azonban a vidék adta egyéb életörömök az általános életminőségét oly mértékben kompenzálják, hogy a biztonság egyes szegmensének volumenében megalkuszik azért, hogy összességében az önönmaga által elvárt biztonságban érezze magát. Úgy vélem tehát, hogy a téma továbbgondolásra - sőt vitára - predesztinált, melyre a tanulmányban felsorakoztatott ismeretek kellő alapot nyújthatnak.

\section{Köszönetnyilvánítás}


A tanulmány a KÖFOP-2.1.2-VEKOP-15-2016-00001 azonosítószámú, „A jó kormányzást megalapozó közszolgálat-fejlesztés" elnevezésü kiemelt projekt keretében, a Nemzeti Közszolgálati Egyetem felkérésére készült.

\section{Irodalomjegyzék}

1. Ajtony Árpád (2013): Dialogizmus, Receptivitás és individuum http://epa.oszk.hu/00000/00015/00068/pdf/EPA00015_Buksz_01_04problema.pdf (letöltés: 2017.10.04.)

2. Bainé Szabó B. (2003): A vidékfejlesztés gazdasági, ökológiai, és társadalmi funkcióinak összefüggése Hortobágy menti településeken, Doktori (Phd) értekezés, Debrecen, Debreceni Egyetem

3. Bakos Ferenc (1994): Idegen szavak és kifejezések kéziszótára. Budapest, Akadémia Kiadó

4. Beregnyei József (szerk.) (2008): A magyar rendészeti szervek által gyakrabban alkalmazott szakmai szócikkek gyüjteménye. Budapest, Magyar Rendészettudományi Társaság

5. Csordás Sándor (2008): A biztonság régi es új szerepe a büntetés-végrehajtásban http://epa.oszk.hu/02700/02705/00074/pdf/EPA02705 bortonugyi szemle_2008_2 033-056.pdf (letöltés: 2017.10.12.)

6. Dávid Gábor (1988): A városi bünözés intenzitása. Belügyi szemle 26. évf. 10. szám

7. Juhász József, Szője István, O Nagy Gábor, Kovalovszky Miklós (1982): Magyar Értelmező kéziszótár. Budapest, Akadémia Kiadó

8. Norbert Elias (1991): La société des individus. Fayard, Paris

9. Patkós Cs., Tóth A. (2012): A bűnözés néhány térbeli jellemzője a rendszerváltás utáni Magyarországon, Területi Statisztika, 52. évfolyam 3. szám, 250-264 p.

10. Szilágyi T., Boldizsár G.: (2016) A biztonságos vidék, mint az állam létfeltétele $P R O$ SCIENTIA RURALIS 1:(4) pp. 24-34. (2016)

11. Tallár Ferenc (szerk.) (2004): Az individuum és az európai tradíció. Szombathely, Savaria University Press

12. Vári Vince (2015): A bünüldözés relatív hatékonysága és a rendörség. Doktori (Phd) értekezés, Miskolc, Miskolci Egyetem 